\title{
HIGH FLOW NASAL OXYGEN THERAPY (HFNO) IN OPPOSITION TO NON-INVASIVE MECHANICAL VENTILATION (NIV): ADVANTAGES, DISADVANTAGES AND THEIR USE IN COVID-19 INFECTION: BRIEF REVIEW
}

\author{
Dmitrovic Radmila, Lazovic Biljana, Simonovic Isidora \\ Department of pulmonology, University Clinical Center “Zemun”, Belgrade, Serbia
}

Primljen/Received 11. 11. 2021. god.

Prihvaćen/Accepted 11. 12. 2021. god.

\begin{abstract}
In the last few decades, different devices for oxygen application have become available, such as low flow systems, high flow systems (HFNO), and non-invasive ventilation (NIV). They are widely applicable and have many advantages as well as disadvantages. HFNO modalities decrease dead space, improve alveolar ventilation, and apply oxygen up to $60 \mathrm{l} / \mathrm{min}$, delivering it humidified and heated opposite NIV, which increases anatomical dead space, maintains adequate minute ventilation, and is used in more conditions than HFNO, etc.

In our research, we included 12 articles. The study was conducted using literature published up from 2013 to July 2020. In our research we used following keywords: 'non-invasive ventilation', 'high-flow nasal oxygen', 'advantages', 'disadvantages', 'COVID-19'.

The HFNO system appears to be more successful than standard oxygen treatment and non-inferior to NIV. It is simple, easy to apply but still insufficiently researched. More research is needed in the future on the benefits and disadvantages of the HFNO system.
\end{abstract}

Keywords: HFNO, NIV, COVID-19, advantages, disadvantages.

\section{INTRODUCTION}

Various oxygen application devices, such as low flow systems (basic facemask, nasal cannula, non-rebreathing reservoir mask) and high flow systems (high-pressure oxygen and air sources, and air-oxygen blender, or a high-flow "Venturi" mask), have been available in recent decades. Alternatives to traditional oxygen therapy include high-flow nasal oxygen therapy (HFNO). HFNO is more sophisticated than the
Venturi mask, which operates on the Bernoulli principle and offers a flow of 30-50 1/min of oxygen and air, with an inspiratory oxygen fraction $\left(\mathrm{FiO}_{2}\right)$ ranging from 24 to $60 \%$. HFNO can supply up to $60 \mathrm{l} / \mathrm{min}$ of heated and completely humidified gas with a $\mathrm{FiO}_{2}$ range from $21 \%$ to $100 \%$ (1). The main indications for HFNO are de novo hypoxemic acute respiratory failure (ARF), in the periods before intubation, prevention of post-extubation ARF, and in immunocompromised patients (2). HFNO has several physiological benefits, including reduced exertion of breathing, the formation of various levels of positive airway pressure (PEEP), the release of a steady $\mathrm{FiO}_{2}$, enhanced mucociliary clearance, patient comfort, and the washout of pharyngeal dead space (1). It is crucial to notice that measuring the basic parameters of the respiratory system is extremely important for assessing its functionality and capacity during a greater or lesser load (3). On the other side, non-invasive mechanical ventilation (NIV) represents ventilatory support with positive airway pressure, where the endotracheal tube, laryngeal mask, or endotracheal cannula are not used to secure the airway. The use of an oronasal mask for NIV is a common practice in both clinical and homecare mechanical ventilation. The system can be used to treat a variety of conditions, including ARF and chronic respiratory failure (CRF) caused by exacerbation of chronic obstructive pulmonary disease (COPD), neuromuscular illnesses, heart failure, immunocompromised individuals, high-risk surgical operations, and respiratory insufficiency following elective extubation $(4,5)$. We will discuss the advantages and disadvantages of HFNO and NIV and examine their imperfections and their use in COVID-19 infection. 


\section{MATERIAL AND METHODS}

We selected substantial studies from databases of PubMed, Embase, and Cochrane library. The following keywords were used: 'non-invasive ventilation', 'high-flow nasal oxygen', 'advantages', 'disadvantages', 'COVID-19 infection'. Headlines, abstracts, and full-text articles of possibly useful studies were independently checked by two researchers. We analyzed papers published in English and Serbian language. The study was conducted using literature published up from 2013 to July 2020. In our research, we included 12 articles.

\section{Comparison and advantages of HFNO and NIV}

HFNO has shown many advantages over conventional devices with low oxygen flow. Devices with low oxygen flow can deliver up to $15 \mathrm{l} / \mathrm{min}$ of oxygen without the ability to heat and humidify it. The HFNO system can apply oxygen up to $60 \mathrm{l} / \mathrm{min}$, delivering it humidified and heated. The ability of the system to humidify and heat the delivered gas has been shown to have a significant physiological effect, especially in critically ill patients. As we mentioned in the introduction, $\mathrm{FiO}_{2}$ in $\mathrm{HFNO}$ is between $21 \%-100 \%$, while in low oxygen systems, $\mathrm{FiO}_{2}$ is inconstant and generally lower than expected. In addition to the physiological advantages, HFNO also has an advantage in how oxygen is delivered. Compared to a basic facemask or nasal cannula, an air/oxygen blender, active heated humidifier, single heated circuit, and high-flow nasal cannula (HFNC) give greater respiratory support, notably the HFNC, which produces medicinal gases at a higher flow and with more predictable $\mathrm{FiO}_{2}$ than other devices in this group. According to some writers, while this open circuit cannot provide high-end expiratory pressure, it does produce PEEP and may raise end-expiratory lung volume (EELV). Many differences can be seen when comparing NIV with HFNO. According to the general literature data, NIV has more indications for usage than HFNO, however, the primary difference between these two modalities is in the interface. HFNC interfaces reduce anatomical dead space, whereas NIV interfaces increase it. When the circuit is open, however, HFNC cannot actively increase tidal volume since there is no effective inspiratory push or expiratory pull (VT). HFNC not only reduces anatomical dead space but also enhances alveolar ventilation. Because of these advantages, which compensate for some of the shortcomings of traditional oxygen delivery systems, and the apparent physiological benefits, the use of HFNC for critically sick people has been steadily rising. On the other hand, to guarantee proper minute ventilation, minute volume was "manipulated" during invasive (MV) or non-invasive (NIV) ventilatory support, particularly for patients with COPD exacerbation, where NIV has been the recommended primary modality for breathing support since it enhances inspiratory VT and maintains optimal alveolar ventilation, but in certain patients, NIV is inapplicable due to inadequate tolerating masks. According to data from various studies, one of the crucial advantages is that HFNO is simple and easy to use and can reduce the use of mechanical ventilation (6). Some authors compared the effects of HFNO versus NIV, emphasizing the primary goal. In one study involving 310 medical intensive care units (ICU), the primary endpoint was intubation, and results showed lower rates in the subgroup of patients with a $\mathrm{PaO}_{2} / \mathrm{FiO}_{2} 200 \mathrm{mmHg}$ (7), while in another involving 49 medical ICU, NIV+HFNO showed higher values of $\mathrm{SpO}_{2}$ during intubation in comparison to the primary endpoint- lowest $\mathrm{SpO}_{2}$ during intubation (8). In one randomized controlled trial (RCT) where the primary goal was to calculate intubation rate, data showed a lower intubation rate with HFNO than with NIV and standard oxygen therapy (9).

\section{Disadvantages}

According to research data, HFNO should be avoided in those patients where NIV is also contraindicated. The crucial point to remember when utilizing an HFNC is that recourse to more invasive care may be delayed, which may be harmful in patients with respiratory instability, therefore in ARF, extended efforts with HFNC may postpone intubation with negative effects (10). Instead, following NIV, its advantages and disadvantages are more researched and better known to the professional public. Leakage is a well-known disadvantage of NIV. Although bridge fans have NIV modes with customized alarm settings, it is unclear how much ventilation is supplied to patients. The measurement of end-tidal carbon dioxide is untrustworthy, and changes to the fan setting may enhance and decrease ventilation by increasing the amount of leakage. What further exacerbates the leakage is the insertion of a nasogastric tube in patients on NIV to reduce gastric pressure and the possibility of aspiration of the contents. The burden for the nurse is also a pivotal disadvantage of NIV in ICU. Patients on NIV require continual attention and particular care, which is not a problem as long as the attending nurse has prior expertise and is solely assigned to NIV patients. A lack of care may increase the risk of deterioration of the patient's condition (11), while other authors also described drying cornea, conjunctivitis, aerophagia, and skin lesions (5). 


\section{The use in COVID-19 infection}

According to Northern Devon Healthcare (NHS), the use of HFNO in suspected or proven COVID-19 infection is not recommended since it is a high-risk aerosol-generating therapy that is also hazardous to the staff (12). Although there are clear contraindications for its use, many researchers have tried HFNO to treat this pandemic. They discovered that HFNO provides a high concentration of oxygen, can reduce the need for intubation in COVID-19 patients, can reduce the length of intensive care unit stay and complications associated with mechanical ventilation, and can achieve apneic oxygenation in patients during airway management. Because HFNC can create aerosols, the treatment should be performed in a negative pressure room, and where this is not practicable devices should be housed in a single room (13). The role of NIV is well-known in treating COVID-19 patients, and its benefit is reflected in the reduced risk to healthcare professionals by eliminating the need for intubation, a potentially highly contagious procedure (14).

\section{CONCLUSION}

According to published statistics, the HFNO system appears to be more successful than traditional oxygen treatment and non-inferior to NIV. It is simple to implement, yet it has received limited investigation. Although its use in COVID-19 infection is prohibited by the NHS, many researchers have dared to apply it by describing the positive effects of its use. However, all of this is still an under-explored field that poses a challenge for future research.
Abbreviations
ARF - acute respiratory failure
COPD - chronic obstructive pulmonary disease
CRF - chronic respiratory failure
EELV - end-expiratory lung volume
$\mathrm{FiO}_{2}$ - inspiratory oxygen fraction
HFNC - high flow nasal cannula
HFNO - high flow nasal oxygen
ICU - intensive care unit
MV - invasive mechanical ventilation
NIV - non-invasive ventilation
NHS - Northern Devon Healthcare
PEEP - positive airway pressure
RCT - randomized controlled trial
VT - tidal volume

\section{Acknowledgment}

None.

Conflict of Interests: The authors declare there are no conflicts of interest related to this article.

\section{Funding: None}

\section{Licensing}

This work is licensed under a Creative Commons Attribution 4.0 International (CC BY 4.0) License.

\title{
Sažetak
}

\section{VISOKO PROTOČNA KISEONIČKA TERAPIJA U POREĐENJU SA NEINVAZIVNOM VENTILACIJOM: PREDNOSTI, NEDOSTACI I NJIHOVA PRIMENA KOD COVID-19 INFEKCIJE: KRATAK PREGLED LITERATURE}

\author{
Dmitrovic Radmila, Lazovic Biljana, Simonovic Isidora \\ Department of pulmonology, University Clinical Center “Zemun”, Belgrade, Serbia
}

U poslednjih nekoliko decenija različiti uređaji za primenu kiseonika su dostupni, kao što su nisko protočni, visoko protočni system (HFNO) i neinvazivna ventilacija (NIV). Rasprostranjeni su širom sveta i imaju mnogo prednosti, ali i svojih mana. Neke od koristi visoko protočnih sistema su: smanjivanje anatomski „mrtvog“ prostora, poboljšanje alveolarne ventilacije i sposobnost primene protoka kiseonika od $60 \mathrm{l} / \mathrm{min}$, isporučujući ga vlažnog i zagrejanog, za razliku od modaliteta neinvazivne ventilacije (NIV) koja ima širu primenu u odnosu na visoko protočne uređaje, dovodi do porasta anatomski „mrtvog“ prostora, održava adekvatnu minutnu ventilaciju itd. $U$ naše istraživanje smo uvrstili podatke iz 12 članaka. Koristili smo literaturu publikovanu u periodu od 2013. do jula meseca 2020. godine. Za pretraživanje literature koristili smo sledeće ključne reči: 'neinvazivna ventilacija', 'visoko protočna kiseonična terapija', 'prednosti', 'mane', 'COVID-19'. Visoko protočni kiseonik je superiorniji u odnosu na nisko protočni, ali i dalje inferioran u odnosu na neinvazivnu ventilaciju. Jednostavan, lak za primenu, ali i dalje nedovoljno istražen. Neophodno je u budućnosti više istraživanja o primeni visoko protočne kiseonične terapije, njenih prednosti i mana.

Ključne reči: visoko protočni, neinvazivna ventilacija, COVID-19, prednosti, mane. 


\section{REFERENCES}

1. Renda T, Corrado A, Iskandar G, Pelaia G, Abdala K, Navalesi P. High-flow nasal oxygen therapy in intensive care and anesthesia. Br J Anaesth. 2018; 120(1): 18-27. doi: 10.1016/j.bja.2017.11.010.

2. Dres M, Demoule A. What every intensivist should know about using high-flow nasal oxygen for critically ill patients. Rev Bras Ter Intensiva. 2017; 29(4): 399-403. doi: 10.5935/0103-507X.20170060.

3. Lazovic B, Dmitrovic R, Simonovic I, Esquinas AM. Baseline physiological measurements: respiratory rate, spontaneous breathing, respiratory effort, and work of breathing. In: Esquinas AM. Principles and practices of non-invasive mechanical ventilation monitoring. From intensive care to home care. New York: Nova Science Publisher; 2021. p. 01-07.

4. Ivanovic M, Petrovic J, Miletic M, Danicic A, Bojovic $\mathrm{B}$, Vukcevic M, et al. Rib-cage-movement measurements as a potential new trigger signal in non-invasive mechanical ventilation. Annu Int Conf IEEE Eng Med Biol Soc. 2015; 2015: 4511-4. doi: 10.1109/EMBC.2015.7319397.

5. Dolinaj V, Lončar T, Božić T, Karišik M, Marković D, Janjević D. Neinvazivna mehanička ventilacija pluća. SJAIT. 2014; 36(1-2): 97-101.

6. Nishimura M. High-flow nasal cannula oxygen therapy in adults: physiological benefits, indication, clinical benefits, and adverse effects. Respir Care. 2016; 61(4): 529-41. doi: 10.4187/respcare.04577.

7. Frat JP, Thille AW, Mercat A, Girault C, Ragot S, Perbet $\mathrm{S}$ et al.High-flow oxygen through nasal cannula in acute hypoxemic respiratory failure. N Engl J Med. 2015; 372(23): 2185-96. doi: 10.1056/NEJMoa1503326.

\section{Correspondence to/Autor za korespondenciju}

Radmila Dmitrovic

University Clinical Center "Zemun"

Belgrade, Serbia

Vukova 9, Zemun, 11080 Belgrade

Self-phone: +381601322400

e-mail: radadmitrovic94@gmail.com
8. Jaber S, Monnin M, Girard M, Conseil M, Cisse M, Carr J et al. Apnoeic oxygenation via high-flow nasal cannula oxygen combined with non-invasive ventilation preoxygenation for intubation in hypoxaemic patients in the intensive care unit: the single-center, blinded, randomized controlled OPTINIV trial. Intensive Care Med. 2016; 42(12): 1877-87. doi: 10.1007/ s00134-016-4588-9.

9. Frat JP, J Ragot S, Girault C, Perbet S, Prat G, Boulain $\mathrm{T}$ et al. Effect of non-invasive oxygenation strategies in immunocompromised patients with severe acute respiratory failure: post hoc analysis of a randomized trial. Lancet Respir Med. 2016; 4(8): 646-52. doi: 10.1016/S2213-2600(16)30093-5.

10. Spicuzza L, Schisano M. High-flow nasal cannula oxygen therapy as an emerging option for respiratory failure: the present and the future. Ther Adv Chronic Dis. 2020; 11: 2040622320920106. doi: 10.1177/2040622320920106.

11. Van der Slujis AF. Non-invasive ventilation; PROs and CONs. Neth J Crit Care. 2013; 17(2): 27-9.

12. Northern Devon Healthcare. Guidelines for high flow nasal oxygen therapy (HFNO) on General Wards. Available from: https://www.northdevonhealth.nhs.uk/wpcontent/ uploads/2020/05/Guidelines-for-High-Flow-Oxygen-TherapyAIRVO\%C2\%B2-Final-v2.0.pdf [cited by 26.12.2020.]

13. Kaya AG, Oz M, Erol S, Ciftci F, Ciledag A, Kaya A. High flow nasal cannula in COVID-19: a literature review. Tuberk Toraks. 2020; 68(2): 168-74. doi: 10.5578/tt.69807.

14. Winck JC, Ambrosino N. Covid-19 pandemic and non-invasive respiratory management: every Goliath needs a David. An evidence-based evaluation of problems. Pulmonology. 2020; 26(4): 213-20. doi: 10.1016/j.pulmoe.2020.04.013.

How to cite this article. Dmitrovic R, Lazovic B, Simonovic I. High flow nasal oxygen therapy (HFNO) in opposition to non-invasive mechanical ventilation (NIV): advantages, disadvantages and their use in COVID-19 infection: brief review. Sanamed.2021;16(3): 227-230 